\title{
REVIEW
}

\section{Head and neck cutaneous basal cell carcinoma: what should the otorhinolaryngology head and neck surgeon care about?}

\author{
Carcinoma basocellulare della cute del distretto \\ testa e collo: cosa dovrebbe valutare il chirurgo \\ otorinolaringoiatra e cervico-facciale?
}

\begin{abstract}
António Castanheira ${ }^{1,2^{*}}$, Paula Boaventura ${ }^{2,3,4^{*}}$, Manuel Pais Clemente ${ }^{2}$, Paula Soares $2,3,4$, Alberto Mota ${ }^{2,5}$, José Manuel Lopes²,3,4

${ }^{1}$ Department of Otorhinolaryngology, Centro Hospitalar de Trás-os-Montes e Alto Douro, Vila Real, Portugal; ${ }^{2}$ FMUP-Faculty of Medicine; ${ }^{3}$ IPATIMUP - Institute of Molecular Pathology and Immunology of the University of Porto, Portugal; ${ }^{4}$ i3S Instituto de Investigação e Inovação em Saúde, University of Porto, Portugal; ${ }^{5}$ Department of Dermatology of Centro Hospitalar São João, Porto, Portugal

${ }^{*}$ A. Castanheira and P. Boaventura contributed equally to this work.
\end{abstract}

\begin{abstract}
SUMMARY
Cutaneous basal cell carcinoma (cBCC) is the most common malignancy diagnosed in the human population. $\mathrm{CBCC}$ presents an increasing incidence which, in the near future, will be higher than all other cancers combined. The majority of $\mathrm{cBCC}$ are located in the head and the neck. A diversity of management modalities is currently available; nonetheless, surgical excision remains the main modality of treatment. $\mathrm{cBCC}$ rarely metastasises and presents a low mortality rate. cBCC morbidity is influenced by local invasion and destruction, especially in the face, where function and aesthetics are major issues. Easy accessibility to the face and skin on the neck makes $\mathrm{cBCC}$ an important issue for otorhinolaryngology head and neck surgeons who must be aware and committed in its management, as the main modality of treatment continues to be surgical. The aim of this review is to present a brief and practical overview of head and neck cBCC management for ear, nose and throat (ENT) surgeons, discussing key issues about its epidemiology, risk factors, diagnosis and pathogenesis.
\end{abstract}

KEY WORDS: basal cell carcinoma, head and neck, ENT surgery, review

\section{RIASSUNTO}

Il carcinoma basocellulare cutaneo $(\mathrm{cBCC})$ è la neoplasia maligna più comunemente diagnosticata nella popolazione umana. La sua incidenza è in aumento e sarà in futuro anche maggiore rispetto alle altre neoplasie. La maggior parte di questi tumori è localizzata a livello del distretto testa e collo. Al momento esistono diverse modalità di trattamento tuttavia la chirurgia rappresenta l'opzione primaria. $c B C C$ tende raramente a metastatizzare ed ha una bassa mortalità, influenzata dal grado di invasione locale. A livello del volto la chirurgia del cBCC deve essere attentamento ponderata da parte del chirurgo per il suo importante impatto a livello estetico e funzionale. Lo scopo di questa review è quello di fornire una concisa e pratica overview della letteratura per il chirurgo otorinolaringoiatra e cervico facciale, sottolineando i keypoints dall'epidemiologia sino ai fattori di rischio, diagnosi e patogenesi del $c B C C$.

PAROLE CHIAVE: carcinoma basocellulare, head and neck, otorinolaringoiatria, review
Received: June 27, 2018

Accepted: September 10, 2018

Published on line: July 31, 2019

Correspondence

Paula Boaventura

i3S - Instituto de Investigação e Inovação em Saúde, Universidade do Porto, rua Alfredo Allen 208,

4200-135 Porto, Portugal

E-mail: mboaventura@ipatimup.pt

\section{Funding}

Funding to P.B. was obtained from FCT grant SFRH/ BPD/111342/2015, and from FCT/MEC through National Funds and co-financed by the FEDER through the PT2020 Partnership Agreement under the project no. 007274 (UID/BIM/04293).

This work was financed by FEDER - Fundo Europeu de Desenvolvimento Regional funds through the COMPETE 2020 - Operational Program for Competitiveness and Internationalization (POCI), Portugal 2020, and by Portuguese funds through FCT - Fundação para a Ciência e a Tecnologia (Ministério da Ciência, Tecnologia e Inovação) in the framework of the project "Institute for Research and Innovation in Health Sciences" (POCI-01-0145-FEDER-007274). Further funding was obtained from the project "Advancing cancer research: from basic knowledge to application"; NORTE-01-0145-FEDER-000029; and "Projetos Estruturados de I\&D\&I", funded by Norte 2020-Programa Operacional Regional do Norte, and from FEDER funds through the Operational Program for Competitiveness Factors - COMPETE and National Funds through the FCT, under the projects "PEst-C/SAU/LA0003/2013". The funding sources had no involvement in study design; collection, analysis and interpretation of data; in the writing of the report; and in the decision to submit the article for publication.

Conflict of interest

The Authors declare no conflict of interest.

How to cite this article: Castanheira A, Boaventura P, Pais Clemente M, et al. Head and neck cutaneous basal cell carcinoma: what should the otorhinolaryngology head and neck surgeon care about? Acta Otorhinolaryngol Ital 2020;40:5-18. https://doi.org/10.14639/0392$100 \mathrm{X}-2245$

๑) Società Italiana di Otorinolaringoiatria e Chirurgia Cervico-Facciale

\section{(c) (1) $(9)$}

This is an open access article distributed in accordance with the CC-BY-NC-ND (Creative Commons Attribution-NonCommercial-NoDerivatives 4.0 International) license. The article can be used by giving appropriate credit and mentioning the license, but only for non-commercial purposes and only in the original version. For further information: https:// creativecommons.org/licenses/by-nc-nd/4.0/deed.en 


\section{Introduction}

Otorhinolaryngology head and neck (ear, nose and throat - ENT) surgeons are often challenged in their daily practice with patients presenting cutaneous cancer. Cutaneous basal cell carcinoma (cBCC) is the most common cancer diagnosed in humans, accounting for $70-80 \%$ of all skin malignancies in fair-skin people, with $80 \%$ occurring in the head and the neck ${ }^{1-3}$.

A logarithmic relationship between age and $\mathrm{cBCC}$ development risk is well established ${ }^{4}$. Life expectancy has been increasing over the past decades, and thus an increasing cBCC incidence is expected in the near future and estimated to be higher than the incidence of all other cancers combined ${ }^{3-6}$. cBCC is a slow growing and locally invasive malignant tumour, which rarely metastasises and presents an extremely low mortality rate. cBCC can be easily treated by surgical excision, particularly when diagnosed early; its morbidity is influenced by local invasion and destruction, especially in the face and the neck, where function and aesthetics are major issues ${ }^{7}$. The increasing longevity of the human population entails the polarisation of pathologies usually managed by ENT surgeons: presbycusis and cancer (particularly face, head and neck cutaneous cancer). Substantial numbers of elderly patients presenting a cBCC risk profile present to ENT outpatient consultation. Hence, the high $\mathrm{cBCC}$ prevalence in the face and neck skin of elderly people demands appropriate expertise by ENT surgeons concerning adequate diagnostic and management practices for patients presenting with this cutaneous cancer.

\section{Epidemiology}

New cases of skin cancer surpass the combined incidence of breast, prostate, lung and colon cancer each year ${ }^{1}$. Cutaneous cancer includes two main groups: malignant melanoma (MM) and non-melanoma skin cancer (NMSC). NMSC comprises two main groups: $\mathrm{cBCC}$ and cutaneous squamous cell carcinoma (cSCC) which are the most common malignancies worldwide and are increasing in incidence ${ }^{8}$. NMSC accounts for more than $95 \%$ of the new cases of cutaneous cancer ${ }^{1}$. In USA, 5.4 million NMSC cases were estimated to occur during 2012, and were diagnosed in 3.3 million people ${ }^{1}$. Lifetime risk of developing $\mathrm{cBCC}$ in the USA is estimated to be greater than $30 \%$ for Caucasians ${ }^{8}$. After an index cBCC case is diagnosed, the incidence of subsequent cases among such patients increases by a factor of 10 compared with the general population ${ }^{9}$. cBCC are usually not recorded in cancer registries due to their low mortality, and often only the first case is registered, but not the subsequent multiple $\mathrm{cBCC}$ in the same patient ${ }^{5,10,11}$. There is a striking variation in the geographical incidence of $\mathrm{cBCC}$, with the highest values in Australia (726 to $884 / 100,000$ person-year) and the lowest in some parts of Africa (less than 1/100,000 person-year) ${ }^{2,5,7}$. In Scotland, Ireland, Wales, England, Finland, Germany, Switzerland, Italy, France and Spain intermediate values have been reported, ranging from $44.6 / 100,000$ to $128 / 100,000$ personyear ${ }^{5,12}$. In Portugal, a study comprising a large series of 3,493 skin malignancies revealed a consistent and gradual increase of $5.0 \%$ per year in $\mathrm{cBCC}^{13}$. Ethnicity differences as well as skin phenotype may explain different distributions in $\mathrm{cBCC}$ incidence, which is higher in fair skinned populations, in a single country or region, and or between countries at the same latitude ${ }^{5}$.

Male gender and age are independent risk factors for $\mathrm{cB}$ $\mathrm{CC}^{8}$. $\mathrm{cBCC}$ incidence is higher in men than in women (1.5-2:1), probably due to professional environments ${ }^{10,14,15}$. cBCC is a malignancy of the elderly, and more than $50 \%$ occur in patients between 50 and 80 years of age ${ }^{2}$. The incidence of $\mathrm{cBCC}$ in a USA population younger than 40 years of age, particularly women, appears to be increasing. cBCC is rare in children and young adults ${ }^{16}$.

cBCC usually develops in chronically sun-exposed skin in the head and the neck (64.5-95.9\%), followed by the trunk $(15-25 \%)$, arms and legs. It has also been reported in other locations such as the axillae, breasts, perianal area, genitalia, palms and soles ${ }^{2,17}$. In the head and the neck, the nose is the most affected area (26-33.4\%), followed by the cheek/ perioral (14.2-23.9\%), forehead/temple (11.2-16.1\%), eyelids $(4.7-8.2 \%)$, ears, pre-auricular region $(6.84-10 \%)$ and neck $(12.4 \%)^{10,17,18}$.

\section{Risk factors}

After age and gender, sunlight exposure is the main risk factor for $\mathrm{CBCC}$, but its pathogenesis remains to be completely understood. cBCC are more frequent in sun-exposed body sites of patients with a strong history of actinic exposure, such as farmers or fishermen ${ }^{2,19-21}$. The main five facial cutaneous anatomical sites (nose, cheek, eye area, forehead and ears) affected by $\mathrm{cBCC}$ correspond closely to the subsites having the greatest UV exposure ${ }^{22}$. $\mathrm{cBCC}$ frequency may be reduced by sun exposure protection measures, but sunscreen use is not clearly associated with decrease of cBCC incidence ${ }^{23}$. Recreational intermittent sun exposure during childhood and adolescence is associated with an increased risk to develop cBCC, showing the importance of some life periods of sun exposure for later life $\mathrm{cBCC}$ risk. This association is stronger among sun-sensitive phenotypes with propensity to burn rather than $\tan ^{24}$. It seems that $\mathrm{CBCC}$ develops following a period of 10 to 50 years after sun exposure causing skin damage ${ }^{15}$. $\mathrm{cBCC}$ incidence rates are in- 
versely associated with latitude. These differences may be explained by greater UV radiation vulnerability of patients in lower latitudes than in higher latitudes ${ }^{5,25}$. The use of tanning beds is reported to be strongly associated with the risk of $\mathrm{cBCC}$ development in a dose-response manner ${ }^{26}$. Patients with distinct phenotypic UV susceptibility traits have different $\mathrm{cBCC}$ incidence rates ${ }^{2,21}$. In fact, $\mathrm{cBCC}$ development is more frequent in light phototypes I and II (Fitzpatrick classification), namely patients with light skin, eyes and hair ${ }^{3,17,27}$. Beyond these constitutional risk factors, other markers of UV susceptibility comprise freckles in childhood, and especially severe sun burns with blistering during childhood ${ }^{28,29}$. Light-skinned people have a probability to develop $\mathrm{cBCC}$ that is 10 to 20 times higher than dark-skinned individuals, even when they cohabit in the same region ${ }^{2,28,29}$. cBCC is uncommon in Blacks, darkskinned people and the Oriental population ${ }^{5}$.

Genome-wide association studies have highlighted some UV radiation susceptibility traits associated with $\mathrm{cBCC}$ that are controlled by common low-penetrance susceptibility alleles in genes related to skin pigmentation, such as ASIP, TYR, OCA2, MC1R and SLC45A2 ${ }^{30,31}$.

Psoralen and ultraviolet A (PUVA) therapy have been related with a moderate risk of $\mathrm{CBCC}^{32}$. Radiotherapy for acne and tinea capitis, a treatment modality no longer used, was associated with a high $\mathrm{cBCC}$ risk ${ }^{33,34}$. In organ transplant recipients submitted to immunosuppression, the incidence of cBCC increases 5- to 16-fold compared with the general population ${ }^{3,35}$.

Chronic arsenic exposure has been reported to be related with an increased risk of $\mathrm{cBCC}^{36}$. Photosensitising drugs in a long-term use, such as tetracycline, deoxycline, sulfonamides, fluoroquinolones, phenothiazines, thiazide diuretics ${ }^{37}$, nonsteroidal anti-inflammatory drugs (NSAIDs) and retinoids have been associated with a higher risk of $\mathrm{CBCC}^{38}$.

\section{Diagnosis and staging}

Identifying suspicious head and neck cutaneous lesions to establish a precise diagnosis is of utmost importance because $\mathrm{cBCC}$ has no known precursor lesion and can present as distinct intricate forms ${ }^{39}$. Lesions with one to several $\mathrm{cm}$, presenting with typical clinical features, can be accurately diagnosed in a regular and fast physical examination. Typical cBCC presents as a pearly pink or flesh coloured nodule with sharp contour, smooth margin and telangiectasia on the surface. Lesions may be translucent or slightly erythematous with a roller border, occasionally together with scaling, crusting, bleeding or ulceration (Fig. 1A). Most $\mathrm{cBCC}$ present as a single lesion, although multiple and simultaneously lesions are not uncommon ${ }^{40}$. The bi-
Table I. Dermatoscopy criteria for $\mathrm{CBCC}$.

$\begin{array}{lc}\text { Dermatoscopy findings } & \text { In-focus dots } \\ \text { Arborising blood vessels } & \text { Maple leaf-like areas } \\ \text { Superficial fine telangiectasia } & \text { Concentric structures } \\ \text { Shiny white-red structureless areas } & \text { Spoke wheel areas } \\ \text { Short white streaks } & \text { Multiple small erosions } \\ \text { Multiple blue-grey nodules } & \text { Ulceration } \\ \text { Blue-grey ovoid nests } & \end{array}$

from Lallas et al., 2014 52; Altamura et al., 2010 55, mod.

ological behaviour of cBCC usually fits the features of a slow growing non-aggressive tumour, taking more than 6 months to achieve one $\mathrm{cm}$ in its largest diameter ${ }^{41,42}$. Median time period between lesion onset and diagnosis is estimated at 37.1 months ${ }^{17}$.

The staging of $\mathrm{cBCC}$ is based on the largest lesion diameter, spreading or infiltration pattern of the surrounding tissues and systemic dissemination (Tab. I) ${ }^{39,43}$.

\section{Clinical subtypes}

cBCC may be classified in three main clinical subtypes: nodular, superficial, and morpheaform. In the same surgical specimen a combination of these subtypes may occur ${ }^{7,44}$. Nodular cBCC corresponds to the most common subtype, representing 38.4-86.9\% of all subtypes, and usually presents the typical features of cBCC (Fig. 1A, B) ${ }^{17,40,45-47}$. The head or the face harbour $90 \%$ of this clinical subtype, particularly the nasolabial folds, cheeks, forehead and eyelids ${ }^{46}$. The differential diagnosis comprises a variety of skin lesions such as molluscum contagiosum, sebaceous hyperplasia, amelanotic melanoma, intradermal melanocytic nevus, Merkel cell carcinoma, fibrous papule of the nose, trichoepithelioma and other adnexal neoplasms, SCC, keratoacanthoma and inflamed seborrheic keratosis ${ }^{48}$.

Superficial cBCC is the second most frequent subtype, representing from $0.6 \%$ to $50.7 \%$ of cases ${ }^{17,45-47}$. It is one of the less aggressive $\mathrm{cBCC}$ subtypes, usually appearing as wellcircumscribed and scarcely infiltrating erythematous-scally plaque, macule, patch or a thin papule (Fig. 1C) ${ }^{40,49}$. Sun protected trunk and extremities are the main locations for these lesions which may be multiple ${ }^{17,40}$. The differential diagnosis includes inflammatory dermatoses such as psoriasis and nummular dermatitis, dermatophytosis, eczema, lichenoid keratosis, actinic keratosis, extra mammary Paget's disease, Bowen's disease and early amelanotic melanoma ${ }^{48}$. Morpheaform BCC is the least frequent subtype, comprising 3.1-12.5\% of cases ${ }^{17,45-47}$. Lesions appear as indurated pink-to-ivory-white, shiny, smooth, scar like plaque of morphea, localised scleroderma, or depressions with illdefined borders; skin atrophy is frequently associated (Fig. 

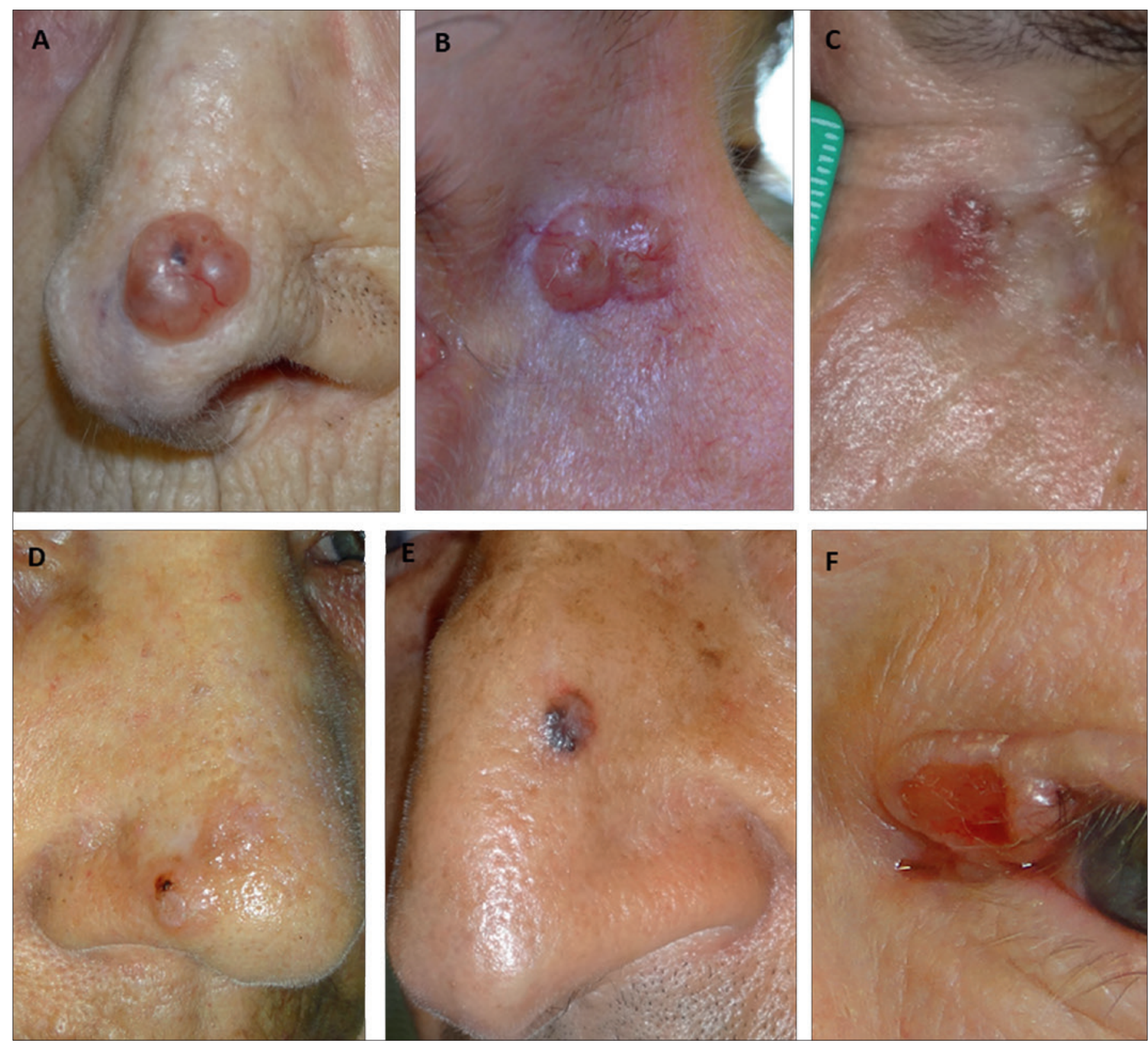

Figure 1. Clinical features of cBCC. A) Nodular; B) Nodular; C) Superficial; D) Morpheaform; E) Pigmented; F) Ulcerated.

1D) ${ }^{40}$. The clinical presentation and evolution are monotonous and subtle, leading to late diagnosis. It usually occurs in the face and the neck, is more aggressive than nodular or superficial $\mathrm{cBCC}$ and portends worse prognosis, higher risk of infiltration and recurrence $40,49,51,52$. The differential diagnosis includes scars, particularly white scar-like lesions (e.g. desmoplastic trichoblastoma), morphea (localised scleroderma), dermatofibrosarcoma protuberans, Merkel cell carcinoma, amelanotic melanoma, microcystic adnexal carcinoma and other adnexal neoplasms ${ }^{48}$.
Other clinical subtypes

The rare $\mathrm{cBCC}$ with abundant pigment - pigmented $\mathrm{cB}$ $\mathrm{CC}-$ is more frequent in darker skin patients and mostly associated with nodular subtypes. They present as elevated and translucent lesions varying from black to blue colour with a pearly white border (Fig. 1E) ${ }^{40,51-53}$. The differential diagnosis includes melanocytic nevi, melanoma and pigmented seborrheic keratosis ${ }^{54}$. The ulcerated cBCC - "rodent ulcer" - occurs as a lesion with a rolled translucent, pearly, firm and smooth border with telangiectasia, often 
Table II. cBCC staging.

\begin{tabular}{|c|c|}
\hline Stage & Features \\
\hline Stage I & $\begin{array}{l}\text { Lesions smaller than } 2 \mathrm{~cm} \text { and limited to the skin with no me- } \\
\text { tastasis }\end{array}$ \\
\hline Sage II & $\begin{array}{l}\text { Lesions larger than } 2 \mathrm{~cm} \text { and limited to the skin and subcutane- } \\
\text { ous tissue with no metastasis }\end{array}$ \\
\hline Stage III & $\begin{array}{l}\text { Lesions of any size invading adjacent structures (e.g. muscle, } \\
\text { cartilage, and bone) such as the orbit, maxilla, mandible and } \\
\text { temporal bone or one lymph node measuring less than } 3 \mathrm{~cm} \\
\text { is involved }\end{array}$ \\
\hline Stage IV & $\begin{array}{l}\text { Lesions with direct or perineural invasion of the skull base, or } \\
\text { more than one lymph node involved or associated with dissemi- } \\
\text { nation to distant organs (e.g. lung, pleura, liver and bone) }\end{array}$ \\
\hline
\end{tabular}

covered with crust, which may result from ulceration of any cBCC subtype. The differential diagnosis includes painless ulcers (Fig. 1F) ${ }^{40}$.

\section{Dermatoscopy}

After direct visual examination, clinicians can perform dermatoscopy, which is particularly useful in uncertain or suspicious lesions, supporting accuracy in diagnosis and differential diagnosis. Dermatoscopy is based on magnification under polarised light for skin inspection, and allows reliable and safe identification of cBCC features (Tab. I). It provides additional information for guiding $\mathrm{cBCC}$ management, although meaningful differences in specificity and predictive value have been reported ${ }^{52,55}$.

\section{Biopsy}

Definitive and precise diagnosis of $\mathrm{cBCC}$ can be achieved only by histology. Biopsy can confirm clinical diagnosis and aims towards subtype identification of cBCC. Importantly, histological examination of the whole lesion is often essential not only for accurate diagnosis of cBCC subtype, but also to ascertain the risk of recurrence after treatment ${ }^{7}$. Biopsy techniques include punch biopsy, shave biopsy, incisional biopsy and excisional biopsy. Punch and shave biopsies have been reported to have almost equal accuracy in the cBCC subtype diagnosis, approximately $80 \%{ }^{56}$. They are simple and easy to perform, but occasionally may not be precise as only a portion of the entire lesion may be represented ${ }^{56}$. The punch biopsy has an overall diagnostic accuracy of $69 \%$, which is higher in single-subtype cBCC $(83 \%)$ and superficial cBCC $(84 \%)$, and lower in mixedsubtype cBCC (37\%) and micronodular cBCC (38\%) ${ }^{57}$. Excision biopsy may be sufficient for concomitant diagnosis and treatment of small $\mathrm{cBCC}$ which do not present high recurrence risk features or cosmetic concerns ${ }^{7}$.

\section{Recurrent and metastatic $B C C$}

$\mathrm{cBCC}$ may be classified as low- or high-risk for recurrence and metastasis, according to their location, size and histopathological features of aggressiveness ${ }^{7,49,58}$. High risk features for single cBCC recurrence are summarised in Table III ${ }^{49,58,59}$.

Recurrence may be due to incomplete tumour excision and the risk increases with tumour size, particularly if the diameter is $>2 \mathrm{~cm}$. The latency period between surgery and onset of recurrence ranges from 2 months to 2 years, although cBCC recurs mostly in the first six months ${ }^{2}$. Perineural invasion is a high-risk feature present in about $1 \%$ of cases. It is frequent in aggressive histopathological subtypes such as infiltrating, morpheaform and basosquamous, particularly in large $\mathrm{cBCC}$ of the face ${ }^{60,61}$. Recurrence is higher in $\mathrm{cBCC}$ arising in previous radiation therapy locations ${ }^{33,34}$. Recurrent cBCC have a worse prognosis than primary lesions as the relationship between tumoural stroma and surrounding tissue may be changed during previous treatment procedures leading to easy spread ${ }^{62}$. Moreover, a

Table III. Major predictors for CBCC recurrence.

$\begin{array}{ll}\text { Tumour and patient features } & \text { High risk features } \\ \text { Size/ location } & \geq 6 \mathrm{~mm} \text { diameter in high-risk locations (central face, eyelids, eyebrows, periorbital, nose, lips, chin, mandible, } \\ & \text { preauricular, ears, postauricular, and temples) } \\ & >10 \mathrm{~mm} \text { diameter in intermediate-risk locations of the head (cheeks, forehead, and scalp) and neck } \\ & >20 \mathrm{~mm} \text { diameter in low-risk areas such as the trunk and the extremities } \\ \text { Borders } & \text { Poorly defined } \\ \text { Primary vs recurrent } & \text { Recurrent } \\ \text { Site of prior radiotherapy } & \text { Yes } \\ \text { Immunosupression } & \text { Present } \\ \text { Aggressive histopathological features } & \text { Morpheaform, sclerosing or mixed infiltrative pattern component in any single lesion } \\ & \text { Micronodular pattern component in any single lesion } \\ & \text { Basosquamous (metatypical) } \\ & \text { Perineural invasion }\end{array}$

from Bichakjian et al., 2016 $6^{59}$, mod. 
first failed treatment approach may lead to recurrent $\mathrm{cBCC}$ with increasing potential of spreading ${ }^{15,62}$.

Lymphatic and haematogenous metastases may occur and are associated with a poor prognosis of $\mathrm{cBCC}$. Incidence of $\mathrm{cBCC}$ metastases varies from 0.0028 to $0.55 \%$ with a few hundred cases reported ${ }^{63-65}$. Median survival for metastatic $\mathrm{cBCC}$ was reported to be 24 months in patients with distant metastases, and 87 months in patients with regional metastases ${ }^{65}$. They are mostly present in regional lymph nodes which are affected in $68 \%$ of cases, but can affect the lungs, pleura, liver and bone ${ }^{41,64}$. Features of cBCC associated with increased risk of metastases are primary $\mathrm{CBCC}$ in high-risk locations, large and locally invasive or recurrent cBCC, male gender, and $\mathrm{cBCC}$ in immunocompromised patients ${ }^{64,66}$.

\section{Extensive subclinical cBCC spread}

Some $\mathrm{cBCC}$ presenting with a high risk of subclinical infiltration need more complex and aggressive management. A risk scale for predicting the $\mathrm{cBCC}$ risk of subclinical spread may assist in patient management (Tab. IV) ${ }^{67}$.

\section{Histopathology}

$\mathrm{cBCC}$ is a malignant epithelial tumour originated in the interfollicular epidermis or follicular epithelium ${ }^{68,69}$. Most histological classifications subdivide $\mathrm{cBCC}$ as nodular, micronodular, superficial, infiltrative and morpheaform, but mixed histology is frequent. The WHO histological classification was adopted in this review (Tab. V) ${ }^{39}$. cBCC can be grouped in two broad categories according to growth features of aggressiveness: indolent-growth subtypes (nodular and superficial) and aggressive-growth subtypes (morpheaform, infiltrative, micronodular, and basosquamous carcinoma) ${ }^{7}$. Aggressive-growth $\mathrm{cBCC}$ subtypes display local invasive behaviour and high recurrence rates ${ }^{7}$.

In micronodular $\mathrm{cBCC}$, tumoural nests extend deeper into the reticular dermis or subcutis and perineural extension can be present. Surgical margins may be underestimated. Superficial cBCC typically shows discontinuous tumoural aggregations giving rise to a multifocal pattern and raising difficulties in the surgical margins assessment ${ }^{39}$. Infiltrative and morpheaform cBCC show dermal or dermal-hypodermal infiltration with frequent mitotic activity and individual tumoural cell necrosis. Perineural invasion is particularly seen in the infiltrative subtype, as well as invasion of subcutis and other adjacent structures, such as muscle ${ }^{39}$. Mixed cBCC comprises $38.5 \%$ of all cases and may be classified according to the most unfavourable subtype $7,39,49,68$. The metatypical cBCC (basosquamous carcinoma) is clinically similar to $\mathrm{cBCC}$, sharing histologic features of $\mathrm{cBCC}$ and
Table IV. Major predictors of extensive subclinical cBCC spread.

Basosquamous, morpheaform, nodular and recurrent $\mathrm{CBCC}$ on the nose
Morpheaform $\mathrm{CBCC}$ on the cheek
Recurrent and nodular $\mathrm{CBCC}$ on the nose
Location on the ear helix, the eyelid and the temple
Location on the neck in men
Recurrent cBCC in men
Preoperative size $>10 \mathrm{~mm}$
from Batra et al., $2002^{67}$, mod.

Table V. WHO histological classification of keratinocytic cutaneous tumours.

\begin{tabular}{l} 
Keratinocytic tumours \\
Basal cell carcinoma \\
Superficial basal cell carcinoma \\
Nodular (solid) basal cell carcinoma \\
Micronodular basal cell carcinoma \\
Infiltrating basal cell carcinoma \\
Fibroepithelial basal cell carcinoma (Pinkus tumour or fibroepithelioma of \\
Pinkus) \\
Basal cell carcinoma with adnexal differentiation \\
Basosquamous carcinoma \\
Keratotic basal cell carcinoma \\
\hline from Kossard et al., $2006^{39}$, mod.
\end{tabular}

cSCC. It shows more aggressive growing features and metastasises more frequently $39,67,68$.

Immunohistochemistry may assist in the differential diagnosis with other malignant skin tumours such as cSCC. Expression of BerEP4 (a monoclonal antibody which recognises two glycopolypeptides expressed in most human epithelial cells) and CD10 (a neutral endopeptidase) is frequent in $\mathrm{cBCC}$, while the expression of epithelial membrane antigen is rare ${ }^{69}$.

\section{Molecular pathogenesis}

cBCC development and progression is the outcome of a multi-step and complex process, resulting from the interaction between genes endowing susceptible traits, genetic mutations and environmental factors, such as UV exposure. Reported genetic changes in Sonic hedgehog (SHH) pathway are considered sufficient to generate the main features of $\mathrm{cBCC}$, although other genetic changes have been reported ${ }^{70}$.

\section{SHH pathway in sporadic BCC and genetic syndromes associated with $B C C$}

SHH pathway is a main signal transduction pathway in embryologic development. In adults, it influences the skin stem-cell population maintenance, regulation of hair follicles and sebaceous gland development, and plays a role in carcinogenesis of many tumours in humans. The $\mathrm{SHH}$ pathway is usually inactivated (in a "turn-off" state) in adult 
cells, and its abnormal activation is associated with the development of several tumours, namely cBCC (Fig. 2) ${ }^{71}$ (for more detail see Fig. 2). Mutations in the PTCH gene are associated with the development of cBCC in $30-75 \%$ of sporadic cases and almost all cases of basal cell nevus syndrome (BCNS) ${ }^{72}$. SMO gene mutations are present in $10-21 \%$ of sporadic cBCC.

Several genetic syndromes should be suspected when multiple cBCC are present, especially at younger ages. Although rare, the most common syndrome is BCNS, also known as Gorlin syndrome, which is an inherited autosomal dominant disorder associated with mutations in the SHH pathway, and specifically in the $P T C H 1, P T C H 2$, and SUFU genes ${ }^{73}$. Constitutive activation of the SHH pathway may act synergistically with changes in the p53 pathway. Mutations in the TP53 gene were reported in up to 50\% of $\mathrm{cBCC}$, and with overexpression in the most aggressive cBCC subtypes; more than two-thirds are UV-induced mutations.

Other genetic changes interacting with environmental fac-

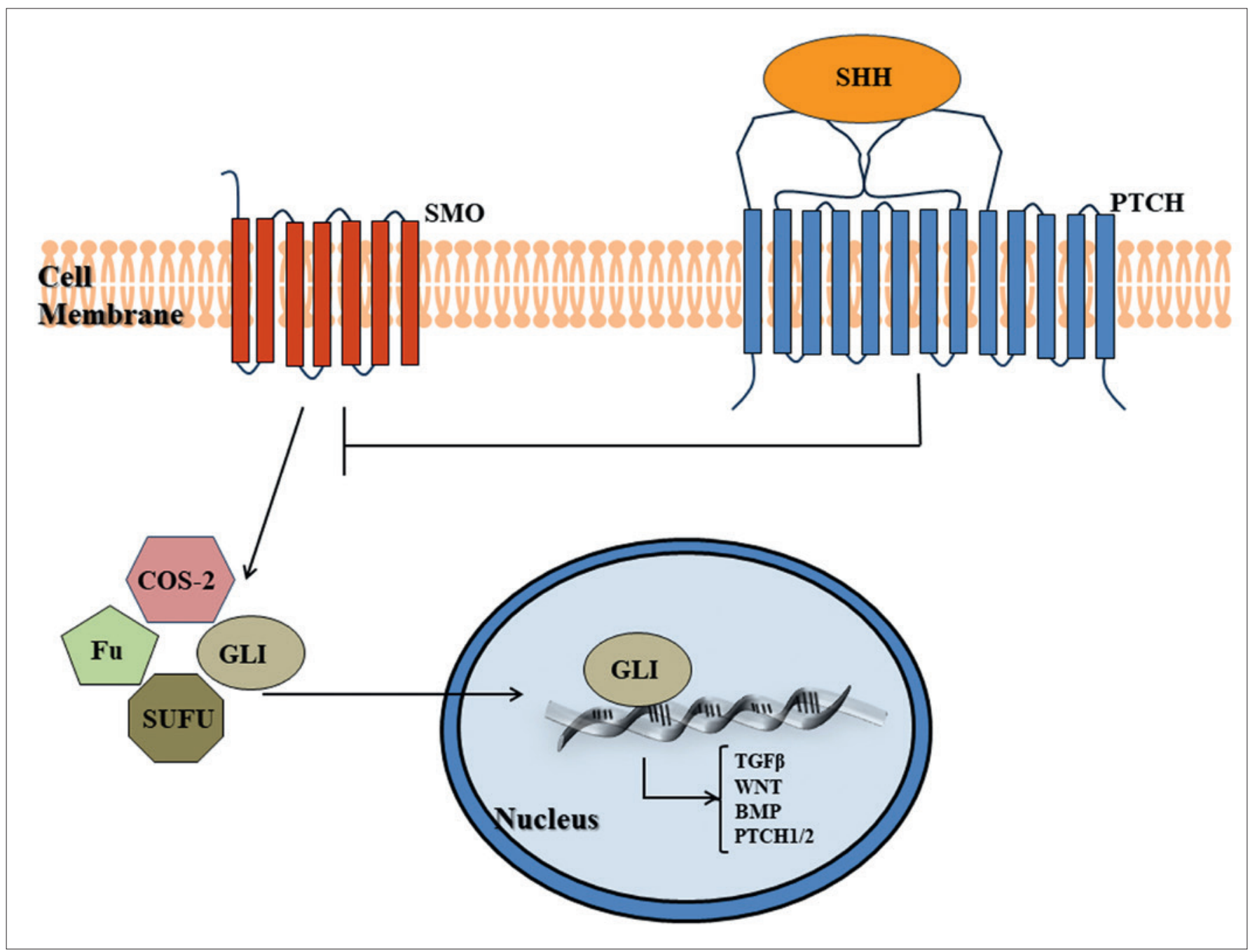

Figure 2. Sonic hedgehog (SHH) pathway. The PTCH1 gene encodes for a receptor protein of the SHH pathway, the Patched1 (PTCH1) receptor. PTCH1 receptor is allocated in the cell plasma membrane and functions as a receptor for ligands of the SHH proteins. PTCH1 receptor constitutively inhibits the next step in SHH pathway. The protein SHH ligand binds to PTCH1 receptor, resulting in a complex in which PTCH1 receptor becomes inhibited releasing the downstream signalling pathway. PTCH1 gene is a tumour suppressor gene as PTCH1 receptor inhibits smoothened (SMO), a seven-transmembrane G-coupled protein receptor expressed by the SMO gene located in chromosome 7q32, which acts as signal transducer of SHH pathway. SMO behaviour is consistent with a proto-oncogene. Activated SMO internalises from plasma membrane and releases GLI proteins from SUFU inhibition which is expressed by SUFU gene located in chromosome 10q24-q25. GLI proteins comprise the transcription factors GLI1, GLI2 and GLI3 which are brought into the cell nucleus. GLI1 protein is a transcriptional activator, while GLI2 and GLI3 proteins may function as activators or as repressors. They have DNA-binding zinc-fingers and activate target genes involved in cell growth and proliferation (PDGFRA, Fox family genes, MYC, cyclins, CTNNB1-, $\beta$-catenin- and RUNX3) (from Madan et al., $2010{ }^{35}$, mod.). 
tors can be associated to $\mathrm{cBCC}$ development, a topic that is beyond the scope of this review ${ }^{74}$. The most recently reported ones are the TERT promoter mutations which are highly prevalent, ranging from $39 \%$ to $74 \%$ in sporadic cBCC (detailed elsewhere) ${ }^{75-77}$.

\section{Management}

The key goal of cBCC management is definitive tumour removal, with radical surgery at first attempt, if possible with preservation of function and aesthetics ${ }^{59,78}$. Low-risk cBCC should not be overtreated, avoiding unnecessary morbidity for the patient and increased costs for the health system. Conversely, aggressive and high-risk $\mathrm{cBCC}$ should not be undertreated in order to avoid recurrence, metastases and further needless high morbidity treatments ${ }^{7}$. Likewise, personal preferences, psychological, social, economic, logistic and health patient conditions must be taken into account, as well as surgeon/physician preferences ${ }^{59}$. Overall, treatment options may comprise surgical and non-surgical therapies.

\section{Surgical therapies}

Standard surgical excision (SSE) with or without reconstruction, Mohs micrographic surgery (MMS), electrosurgery (electro dissection and curettage - ED\&C), carbon-dioxide laser surgery, and cryosurgery are possible alternatives to be considered in each case ${ }^{78}$.

SSE. Surgical removal of the entire lesion with clear margins is standard treatment for $\mathrm{cBCC}$. Surgical excision is followed by primary closure or reconstruction with tissue flaps, skin grafts, or healing by secondary intention ${ }^{59}$. In some patients, the surgical wound is closed after definitive histopathological diagnosis.

Primary $\mathrm{cBCC}$ in the head and the neck have a variable recurrence rate related to size, $3-5 \%$ for tumours $<6 \mathrm{~mm}^{79,80}, 8 \%$ for tumours 6-9 $\mathrm{mm}$ size ${ }^{79}$ and $9-23 \%$ for tumours $>10 \mathrm{~mm}$ in diameter ${ }^{79,80}$. The highest recurrence rates after surgical excision are reported in the nose, periocular, paranasal and scalp areas ${ }^{7}$. The incidence of incompletely excised cBCC varies among different reports and seems to be influenced by the surgeon's experience, anatomical location (higher in the head and the neck) and histological subtype (higher in the mixed and sclerosing subtypes) ${ }^{7}$. Most $\mathrm{cBCC}$ with positive margins are disease-free after 5 years and will not recur, probably as a consequence of tumour remnants destruction during cicatrisation ${ }^{81}$. Nonetheless, a mean recurrence rate of $26-27 \%$ is reported in these $\mathrm{cBCC}^{81,82}$, a value that may be underestimated as many patients with a relapse after incomplete excision do not return to the previous surgeon, being treated in another centre.
Management of incompletely excised cBCC has no consensus until today. When incompletely excised at the deep margin, a high-risk cBCC with aggressive clinical/histopathological features should be re-excised, preferentially by MMS ${ }^{7}$. Recurrent cBCC managed with surgical excision display recurrence rates of 11-17\% during 5-year follow-up, which indicates that they should be treated by MMS ${ }^{79,83}$.

Adequate width for surgical margins clearance assuring maximal cure rate of $\mathrm{CBCC}$ is usually decided taking into account several factors: the clinical presentation of the primary tumour, recurrent or incompletely excised tumour, anatomical site and local features, clinical and histopathological subtype and subclinical tumour extension. Physician choices based on personal experience also support decisions concerning the width of surgical margins ${ }^{7,59,82}$. Nodular $\mathrm{CBCC}$ on the face should be excised with standard $4 \mathrm{~mm}$ margins to ensure best cure rates ${ }^{84}$. Nevertheless, $4 \mathrm{~mm}$ margins are not always feasible and desirable on the face, where functional and aesthetic issues should be considered. In these cBCC, a $3 \mathrm{~mm}$ margin may be effective, attaining a $95 \%$ cure rate ${ }^{82}$ when performed according to the three-dimensional growing of the tumour.

Alternatively, MMS may be performed for complete tumour excision and tissue sparing, taking into account tumour size and location, as well as the aggressiveness of the $\mathrm{cBCC}^{84}$. A feasible and pragmatic algorithm for surgical management of primary and recurrent $\mathrm{cBCC}$ is presented in Figure $3^{85,86}$.

Surgical excision is fast, inexpensive and well accepted, and usually has good long-term functional and aesthetic outcomes. It is often a straightforward office-based procedure, performed under local anaesthesia, and provides information about surgical margins. Its disadvantages encompass longer time spent in reconstructive cases, higher costs than cryosurgery and ED\&C, invasiveness issues and loss of potential healthy tissue associated to poorer functional/ cosmetic results ${ }^{7,82}$. The main limitation of this technique is the failure to accurately detect $\mathrm{cBCC}$ in surgical margins (under diagnosis), conceding lower cure rates than MMS in high-risk $\mathrm{cBCC}^{87}$. An active collaboration between a surgeon and pathologist is desirable, but not always achievable when the resection is an office-based procedure.

$M M S$. Mosh micrographically controlled surgery or histopathological controlled excision comprises a sequence of steps combining surgical excisions with frozen section histopathological evaluations of complete, or almost complete, epidermal and deeper surgical margins. The cycle excision/histologic evaluation may be repeated according to the histopathological results until clear and safe margins are achieved ${ }^{88,89}$ (Fig. 4). The MMS recurrence rate for primary $\mathrm{cBCC}$ has been reported to be $1.4 \%$ in a 5-year period of follow-up, whereas for 


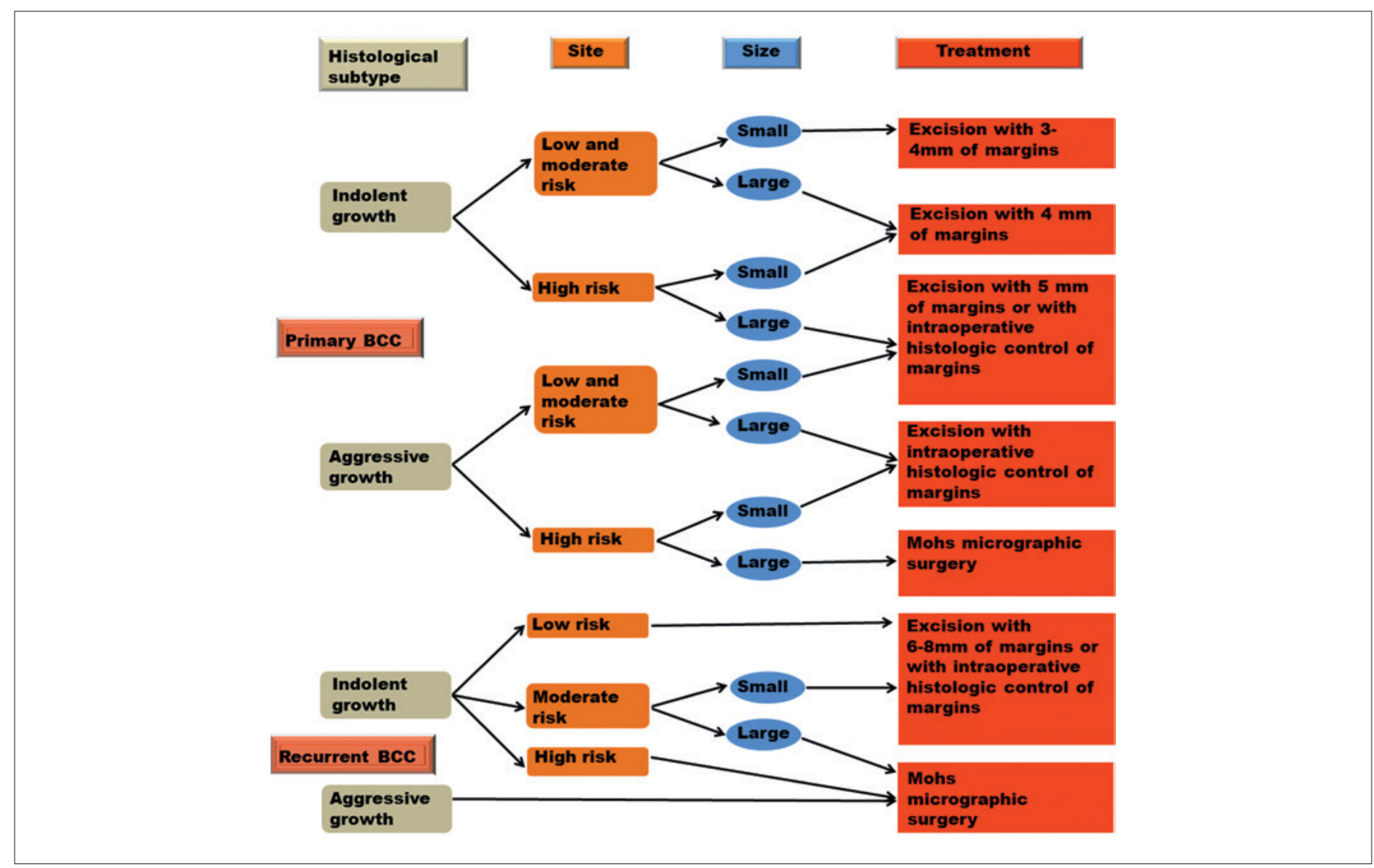

Figure 3. Algorithm for surgical management of primary and recurrent CBCC. Indolent: nodular and superficial. Aggressive: infiltrative, sclerosing and metatypical. Low risk: trunk and extremity. Intermediate risk: scalp, neck, forehead and cheek. High risk: centrofacial, nose, temple, periocular region, perioral and ears. Large lesions: larger than 1cm in high-risk areas; larger than $2 \mathrm{~cm}$ in intermediate-risk areas; larger than $4 \mathrm{~cm}$ in low-risk areas (from Luz et al., 2016 85; Luz et al., $2015^{86}$, mod.).

recurrent tumours $4 \%$ was reported in the same period ${ }^{88}$, establishing MMS as a treatment of choice not only for primary, but mainly for recurrent $\mathrm{cBCC}{ }^{83}$.

MMS is suitable for the treatment of high risk or aggressive-growth histologic cBCC subtypes allowing intra-operative margin control in a short period of time (minutes to few hours) and in an outpatient setting under local anaesthesia ${ }^{88,90}$. In these cases, radical excision may be associated with good function and cosmetic outcomes, as sparing ability of surrounding tissue by MMS allows smaller defect areas comparing with $\mathrm{SSE}^{7}$. Its disadvantages comprise invasiveness, financial cost and special techniques requiring more time, laboratory equipment, microscope and specialised pathologists for intra-operatory procedures ${ }^{7,59,87}$.

\section{Electrodessication and curettage $(E D \& C)$}

This technique combines a superficial ablation by electrodissection and surgical scraping of the affected skin with a curette. Classically ED\&C is performed in two or three rounds of electrodissection and curettage ${ }^{80}$. ED\&C is fast, easy to perform, and well tolerated. It is indicated in primary low-risk cBCC, specifically in the trunk and limbs, where it achieves low recurrence rates. In tumours demanding more than one cycle of electro fulguration and curettage, excision (SSE or MMS) should be the preferred method, allowing a reliable histological assessment ${ }^{59}$. The most common adverse effect is a hypopigmented scar, which makes ED\&C less reasonable in the face ${ }^{80}$.

Cryosurgery. This technique consists of the use of liquid nitrogen to destroy tumour tissue by freezing. It is rarely applied with a curative intent due to the high recurrence rate. It does not allow histological evaluation, and can lead to a hypopigmented scar ${ }^{7,59}$. Nevertheless, in patients who refuse surgery or without conditions for other invasive procedures (elderly, high-risk surgical patients, patients with a coagulopathy or a pacemaker), cryosurgery may be an option. Performed in outpatient setting, this procedure is inexpensive, fast and usually safe ${ }^{59}$. 


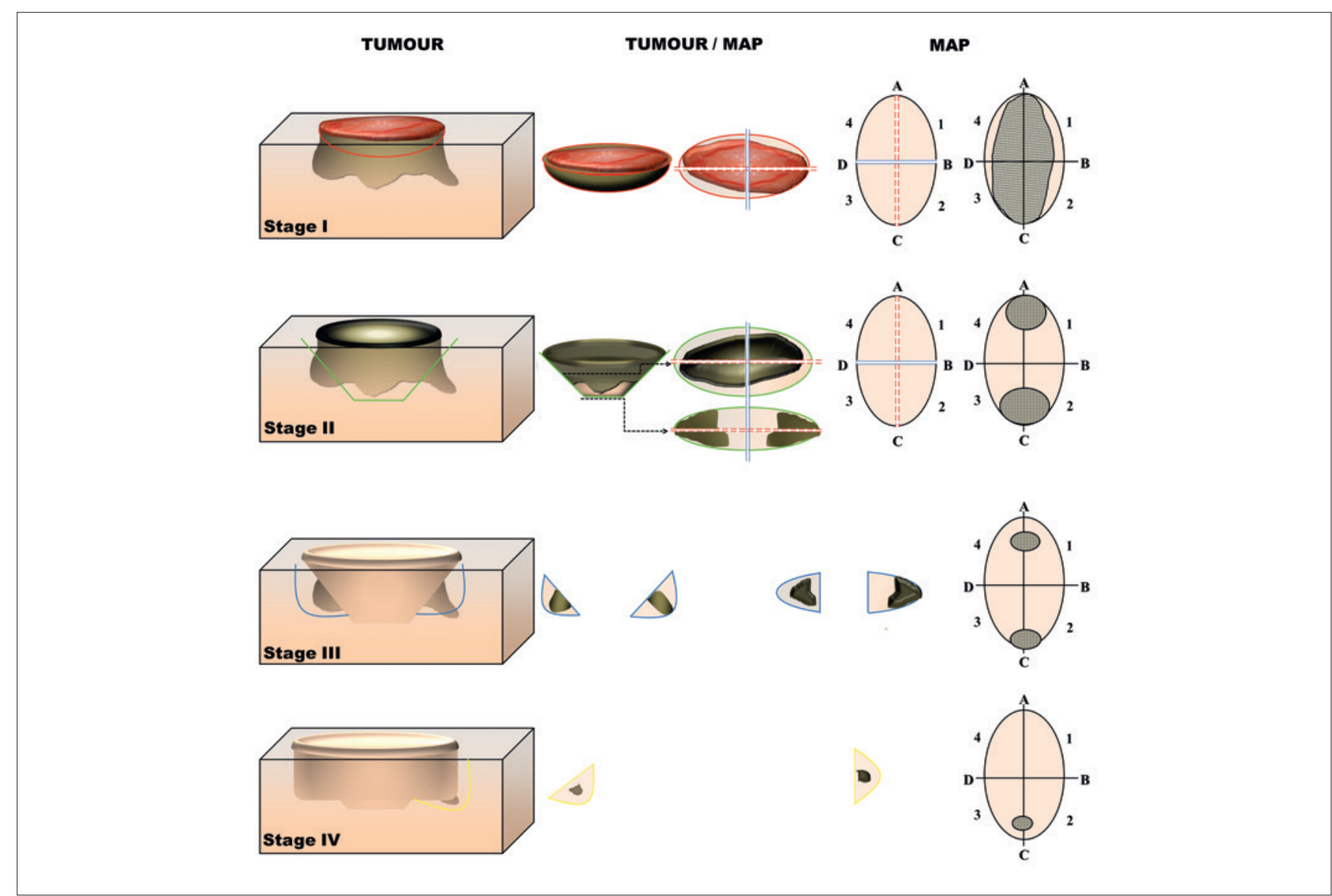

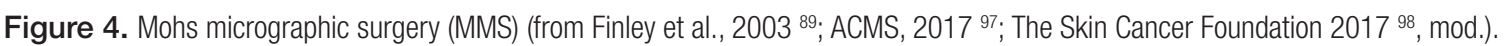

Carbon-dioxide (CO2) laser surgery. Although an uncommon treatment option, $\mathrm{CO} 2$ laser surgery can be used to remove $\mathrm{cBCC}$, and is useful in patients with coagulopathy because it accomplishes a bloodless surgical field. Minimal postoperative pain and discomfort, as well as good long term functional and aesthetic results, are reported. The disadvantages, beyond financial and logistics issues, are the wide range of recurrences rates ${ }^{7}$.

\section{Topical medical therapies}

Imiquimod is a toll-like receptor (TLR) 7 and 8 agonist that activates the nuclear factor kappa B (NFKB), inducing interferon and other cytokines. It is assumed to promote $\mathrm{T}$ cell-mediated apoptosis of tumour cells, tricking survival mechanisms ${ }^{7}$. Imiquimod, as topical imiquimod 5\% cream, was approved by the FDA for superficial $\mathrm{cBCC}$ in low-risk locations and is indicated for the treatment of primary tumours in which recurrence and subsequent treatment does not carry relevant functional and cosmetic morbidity ${ }^{7}$.

Topical 5-flurouracil (5-FU) (5\% formulation) causes cyto- toxicity through inhibition of thymidylate synthase interfering with DNA replication and repair ${ }^{91}$. 5-FU was approved by the FDA for superficial cBCC in low-risk locations, and may be an alternative to imiquimod, although it has been now replaced by imiquimod. It is well-tolerated, offering a generally good cosmetic outcome and high levels of patient satisfaction ${ }^{59,92}$.

Topical medical therapies are easy to self-apply and are thus options in small and multiple low-risk localisations of $\mathrm{cBCC}$ for patients lacking the conditions for SSE. Conversely, local adverse effects may cause more annoying and unfavourable reactions and outcomes in facial lesions compared to MMS ${ }^{93}$.

\section{Other therapies}

In photodynamic therapy (PDT), a combination of light and porphyrins is used for $\mathrm{cBCC}$ ablation. Illumination in the red light narrow band at $570-670 \mathrm{~nm}\left(75 \mathrm{~J} / \mathrm{cm}^{2}\right)$ is regularly used. The prodrugs applied are 5-aminolaevulinic acid (ALA) and its lipophilic methyl ester, methyl aminolae- 
vulinate (MAL). PDT was approved for $\mathrm{cBCC}$ treatment in many countries in Europe ${ }^{7}$. Superficial $\mathrm{CBCC}$ are the major subtypes indicated for this modality with overall cure rates varying from $70 \%$ to $90 \%{ }^{59}$. Adverse effects include pain or burning sensation at administration, erythema, itching, epithelial exfoliation and pustules ${ }^{7,59}$.

Radiotherapy (RT) is not indicated as a first line treatment for $\mathrm{CBCC}$ unless surgery is contraindicated. RT displays a low recurrence rate in $\mathrm{cBCC}$ treatment, $7.4 \%$ for primary and $9.5 \%$ for recurrent $\mathrm{cBCC}{ }^{94}$. Common adverse effects, such as permanent skin hypopigmentation or hyperpigmentation, dryness, epidermal atrophy, telangiectasia and dermal fibrosis are reported in $37 \%$ of patients with $\mathrm{cBCC}{ }^{94}$. Chronic radiation dermatitis, alopecia and radiation-induced skin malignancies limit the indications for radiotherapy, making it more suitable for patients with more than 60 years of age in whom surgery is not possible or not desired ${ }^{94}$.

Chemotherapy (platinum-based therapy) has been used for management of uncontrolled local and metastatic cBCC. However, the patient's comorbidities must be considered: proper kidney function is required and bone marrow toxicity may occur ${ }^{7}$.

\section{Targeted medical therapies}

In some cBCC complete surgical resection may be impossible without compromising not only aesthetics, but also vital or functional important structures. Additionally, radiotherapy may be ineffective or contraindicated. Local advanced and metastatic $\mathrm{cBCC}$ have been a challenging issue, emphasising the importance of the new emerging medical therapies, such as the anti-SMO agents.

Vismodegib, an inhibitor of the SMO receptor in the hedgehog pathway, is a new systemic therapeutic option for advanced cBCC. This drug was approved by the FDA in 2012 for the treatment of locally advanced and metastatic $\mathrm{cBCC}^{95}$. Sekulic et al. reported objective responses in $43 \%$ of patients with locally advanced $\mathrm{CBCC}$ and in $30 \%$ of patients with metastatic cBCC treated with Vismodegib ${ }^{96}$. Its common adverse events comprise muscle spasms, alopecia, taste disturbance, weight loss and fatigue ${ }^{95,96}$.

Ingenol mebutate gel has been reported to have promising results in clinical trials, with a stated histological clearance between $38 \%$ and $63 \%$. On the other hand, its main indication is the treatment of actinic keratosis and not cBCC. Adverse events include erythema, flaking and scaling, pain and headache ${ }^{7}$.

Surgical modalities often achieve cure of $\mathrm{cBCC}$ with good oncological, functional and cosmetic efficiency. Low-risk cBCC can be treated with ED\&C or mainly with SSE. High-risk and recurrent $\mathrm{cBCC}$ should undergo aggressive management. In this setting, MMS is considered the gold standard treatment of choice, providing the highest cure rates and best aesthetic outcomes ${ }^{7,59}$.

\section{Prognosis and prevention}

Overall, prognosis of $\mathrm{cBCC}$ is good and defined by the likelihood of cure or risk of recurrence. During follow-up two major issues must be taken into account: the risk of local invasion and recurrence, and although very rare, the management of metastatic $\mathrm{CBCC}^{78}$.

The main prevention strategy should consist of measures addressing protection from UV exposure during childhood and adolescence, especially in fair skin people. Despite being a controversial issue, the regular use of sunscreens with a solar protector factor (SPF) of 15 has been associated with a reduction in the lifetime incidence of $\mathrm{cBCC}^{7,23}$. The use of sunscreen can be advised as it may prevent melanoma and may have a role in cBCC prevention, especially in organ transplant recipients ${ }^{7}$. Self-skin examination of susceptible patients in a routine-based practice, and outpatient consultation referral when suspicious lesions are present, are of utmost importance in early detection and diagnosis of $\mathrm{cBCC}$.

\section{Conclusions}

$\mathrm{cBCC}$ is, and will continue to be, a major public health problem because of its growing incidence, causing an increased financial burden to healthcare systems ${ }^{8}$. Hence, it is very important that physicians assisting patients with high risk of developing $\mathrm{CBCC}$ attain clinical competence on this common oncological topic. cBCC are mainly located on the head and the neck, making these lesions a significant issue for ENT surgeons who must be aware and committed to take part in its management since the main treatment modality is surgery.

\section{References}

1 ACS (American Cancer Society). Cancer facts \& figures 2017. Atlanta: American Cancer Society 2017. www.cancer.org

2 Chinem VP, Miot HA. Epidemiology of basal cell carcinoma. An Bras Dermatol 2011;86:292-305. https://doi.org/10.1590/s036505962011000200013

3 Rubin AI, Chen EH, Ratner D. Basal-cell carcinoma. N Engl J Med 2005;353:2262-9. https://doi.org/10.1056/NEJMra044151

4 Holm AS, Nissen CV, Wulf HC. Basal cell carcinoma is as common as the sum of all other cancers: implications for treatment capacity. Acta Derm Venereol 2016;96:505-9. https://doi.org/10.2340/00015555-2282

5 Lomas A, Leonardi-Bee J, Bath-Hextall F. A systematic review of worldwide incidence of nonmelanoma skin cancer. $\mathrm{Br}$ J Dermatol 2012;166:1069-80. https://doi.org/10.1111/j.13652133.2012.10830.x 
6 WHO. World Health Statistics 2016: monitoring health for the SDGs, sustainable development goals. Geneva: World Health Organization; 2016. https://www.who.int/gho/publications/world_health_statistics/2016/en/

7 Trakatelli M, Morton C, Nagore E, et al. Guidelines on the treatment of basal cell carcinoma. European Dermatology Forum 2012. http:// www.euroderm.org/edf/index.php/edf-guidelines/category/5-guidelines-miscellaneous

8 Cameron M, Lee E, Hibler B, et al. Basal cell carcinoma: epidemiology; pathophysiology; clinical and histological subtypes; and disease associations. J Am Acad Dermatol 2019;80:303-17. https://doi. org/10.1016/j.jaad.2018.03.060

9 Marcil I, Stern RS. Risk of developing a subsequent nonmelanoma skin cancer in patients with a history of nonmelanoma skin cancer: a critical review of the literature and meta-analysis. Arch Dermatol 2000;136:1524-30. https://doi.org/10.1001/archderm.136.12.1524

10 Richmond-Sinclair NM, Pandeya N, Ware RS, et al. Incidence of basal cell carcinoma multiplicity and detailed anatomic distribution: longitudinal study of an Australian population. J Invest Dermatol 2009;129:323-8. https://doi.org/10.1038/jid.2008.234

11 de Vries E, Micallef R, Brewster DH, et al. Population-based estimates of the occurrence of multiple vs first primary basal cell carcinomas in 4 European regions. Arch Dermatol 2012;148:347-54. https:// doi.org/10.1001/archdermatol.2011.2244

12 Trakatelli M, Morton C, Nagore E, et al. Update of the European guidelines for basal cell carcinoma management. Eur J Dermatol 2014;24:312-29. https://doi.org/10.1684/ejd.2014.2271

13 Andrade P, Brites MM, Vieira R, et al. Epidemiology of basal cell carcinomas and squamous cell carcinomas in a Department of Dermatology: a 5 year review. An Bras Dermatol 2012;87:212-9. https:// doi.org/10.1590/s0365-05962012000200004

14 Hoban PR, Ramachandran S, Strange RC. Environment, phenotype and genetics: risk factors associated with BCC of the skin. Expert Rev Anticancer Ther 2002;2:570-9. https://doi. org/10.1586/14737140.2.5.570

15 Roewert-Huber J, Lange-Asschenfeldt B, Stockfleth E, et al. Epidemiology and aetiology of basal cell carcinoma. Br J Dermatol 2007;157(Suppl 2):47-51. https://doi.org/10.1111/j.13652133.2007.08273.x

16 Christenson LJ, Borrowman TA, Vachon CM, et al. Incidence of basal cell and squamous cell carcinomas in a population younger than 40 years. JAMA 2005;294:681-90. https://doi.org/10.1001/ jama.294.6.681

17 Mantese SAO, Berbert ALCV, Gomides MDA, et al. Carcinoma basocelular - Análise de 300 casos observados em Uberlândia - MG. An Bras Dermatol 2006;81:136-42. http://www.scielo.br/pdf/\%0D/abd/ v81n2/v81n02a04.pdf

18 Souza CF, Thome EP, Menegotto PF, et al. Topography of basal cell carcinoma and their correlations with gender, age and histologic pattern: a retrospective study of 1042 lesions. An Bras Dermatol 2011;86:272-7. https://doi.org/10.1590/s0365-05962011000200010

19 Maia M, Proenca NG, de Moraes JC. Risk factors for basal cell carcinoma: a case-control study. Rev Saude Publica 1995;29:27-37. https://doi.org/10.1590/s0034-89101995000100006

20 Rocha FPd, Menezes AMB, Almeida Junior HLd, et al. Marcadores e fatores de risco para queratoses actínicas e carcinomas basocelulares: um estudo de caso-controle. An Bras Dermatol 2004;79:441-54. http://www.scielo.br/pdf/\%0D/abd/v79n4/v79n04a06.pdf

${ }_{21}$ Armstrong BK, Kricker A. The epidemiology of UV induced skin cancer. J Photochem Photobiol B 2001;63:8-18. https://doi.org/10.1016/ S1011-1344(01)00198-1

22 Diffey BL, Tate TJ, Davis A. Solar dosimetry of the face: the relation- ship of natural ultraviolet radiation exposure to basal cell carcinoma localisation. Phys Med Biol. 1979;24:931-9. https://iopscience.iop. org/article/10.1088/0031-9155/24/5/006/pdf

23 Green A, Williams G, Neale R, et al. Daily sunscreen application and betacarotene supplementation in prevention of basal-cell and squamous-cell carcinomas of the skin: a randomised controlled trial. Lancet 1999;354:723-9. https://doi.org/10.1016/S0140-6736(98)12168-2

24 Gallagher RP, Hill GB, Bajdik CD, et al. Sunlight exposure, pigmentary factors, and risk of nonmelanocytic skin cancer. I. Basal cell carcinoma. Arch Dermatol 1995;131:157-63. https://doi.org/10.1001/ archderm.1995.01690140041006

25 Chuang TY, Popescu A, Su WP, et al. Basal cell carcinoma. A population-based incidence study in Rochester, Minnesota. J Am Acad Dermatol 1990;22:413-7. https://doi.org/10.1016/0190-9622(90)70056-n

26 Zhang M, Qureshi AA, Geller AC, et al. Use of tanning beds and incidence of skin cancer. J Clin Oncol 2012;30:1588-93. https://doi. org/10.1200/JCO.2011.39.3652

27 Fitzpatrick TB. The validity and practicality of sun-reactive skin types I through VI. Arch Dermatol 1988;124:869-71. https://doi. org/10.1001/archderm.1988.01670060015008

28 Zanetti R, Rosso S, Martinez C, et al. Comparison of risk patterns in carcinoma and melanoma of the skin in men: a multi-centre case-casecontrol study. Br J Cancer 2006;94:743-51. https://doi.org/10.1038/ sj.bjc. 6602982

29 Kricker A, Armstrong BK, English DR, et al. Pigmentary and cutaneous risk factors for non-melanocytic skin cancer - a case-control study. Int J Cancer 1991;48:650-62. https://doi.org/10.1002/ijc.2910480504

30 Gudbjartsson DF, Sulem P, Stacey SN, et al. ASIP and TYR pigmentation variants associate with cutaneous melanoma and basal cell carcinoma. Nat Genet 2008;40:886-91. https://doi.org/10.1038/ng.161

31 Nan H, Kraft P, Hunter DJ, et al. Genetic variants in pigmentation genes, pigmentary phenotypes, and risk of skin cancer in Caucasians. Int J Cancer 2009;125:909-17. https://doi.org/10.1002/ijc.24327

32 Stern RS, Study PUFA Follow-up Study. The risk of squamous cell and basal cell cancer associated with psoralen and ultraviolet A therapy: a 30-year prospective study. J Am Acad Dermatol 2012;66:55362. https://doi.org/10.1016/j.jaad.2011.04.004

33 Lichter MD, Karagas MR, Mott LA, et al.; The New Hampshire Skin Cancer Study Group. Therapeutic ionizing radiation and the incidence of basal cell carcinoma and squamous cell carcinoma. Arch Dermatol 2000;136:1007-11. https://doi.org/10.1001/archderm.136.8.1007

34 Boaventura P, Oliveira R, Pereira D, et al. Head and neck basal cell carcinoma prevalence in individuals submitted to childhood X-ray epilation for tinea capitis treatment. Eur J Dermatol 2012;22:225-30. https://doi.org/10.1684/ejd.2012.1670

35 Madan V, Lear JT, Szeimies RM. Non-melanoma skin cancer. Lancet 2010;375:673-85. https://doi.org/10.1016/S0140-6736(09)61196-X

36 Karagas MR, Tosteson TD, Blum J, et al. Design of an epidemiologic study of drinking water arsenic exposure and skin and bladder cancer risk in a U.S. population. Environ Health Perspect 1998;106(Suppl 4):1047-50. https://doi.org/10.1289/ehp.98106s41047

37 Karagas MR, Stukel TA, Umland V, et al. Reported use of photosensitizing medications and basal cell and squamous cell carcinoma of the skin: results of a population-based case-control study. J Invest Dermatol 2007;127:2901-3. https://doi.org/10.1038/sj.jid.5700934

38 Robinson SN, Zens MS, Perry AE, et al. Photosensitizing agents and the risk of non-melanoma skin cancer: a population-based case-control study. J Invest Dermatol 2013;133:1950-5. https://doi. org/10.1038/jid.2013.33

39 Kossard S, Epstein EHJ, Cerio R, et al. Keratinocytic tumours - basal cell carcinoma. Lyon, France: World Health Organization 2006. https://www.iarc.fr/en/publications/pdfs-online/.../bb6-cover.pdf 
40 Carucci JA, Pettersen DJLJS. Chapter 115. Basal cell carcinoma. In: Hill M (ed.). Fitzpatrick's Dermatology in General Medicine. New York, NY: McGraw-Hill; 2012. https://accessmedicine.mhmedical. com/content. aspx ?bookid $=392 \&$ sectionid $=41138832$

41 Kopke LF, Schmidt MS. Carcinoma basocelular. An Bras Dermatol 2002;77:249-82.

42 Kirkup ME, De Berker DA. Clinical measurement of dimensions of basal cell carcinoma: effect of waiting for elective surgery. Br J Dermatol 1999;141:876-9. https://doi.org/10.1046/j.13652133.1999.03111.x

43 Edge SB, Byrd DR, Compton CC, et al. AJCC cancer staging manual. Berlin: Springer; 2010. https://doi.org/10.1245/s10434-010-0985-4

${ }^{4}$ Correia de Sa TR, Silva R, Lopes JM. Basal cell carcinoma of the skin (part 2): diagnosis, prognosis and management. Future Oncol 2015;11:3023-38. https://doi.org/10.2217/fon.15.246

45 Sobral Filho JF BG, Ramalho GL, et al. Variaveis epidemiologicas do carcinoma basocelular na Paraiba. CCS 1995;14:38-45.

46 Scrivener Y, Grosshans E, Cribier B. Variations of basal cell carcinomas according to gender, age, location and histopathological subtype. Br J Dermatol 2002;147:41-7. https://doi.org/10.1046/j.13652133.2002.04804.x

47 Bernard P, Dupuy A, Sasco A, et al. Basal cell carcinomas and actinic keratoses seen in dermatological practice in France: a cross-sectional survey. Dermatology 2008;216:194-9. https://doi. org/10.1159/000112925

48 Marzuka AG, Book SE. Basal cell carcinoma: pathogenesis, epidemiology, clinical features, diagnosis, histopathology, and management. Yale J Biol Med 2015;88:167-79. https://europepmc.org/articles/ pmc4445438

49 Dandurand M, Petit T, Martel P, et al. Management of basal cell carcinoma in adults Clinical practice guidelines. Eur J Dermatol 2006;16:394-401.

50 Pelucchi C, Di Landro A, Naldi L, et al.; Oncology Study Group of the Italian Group for Epidemiologic Research in D. Risk factors for histological types and anatomic sites of cutaneous basal-cell carcinoma: an italian case-control study. J Invest Dermatol 2007;127:935-44. https://doi.org/10.1038/sj.jid.5700598

51 Menzies SW, Westerhoff K, Rabinovitz H, et al. Surface microscopy of pigmented basal cell carcinoma. Arch Dermatol 2000;136:1012-6. https://doi.org/10.1001/archderm.136.8.1012

52 Lallas A, Apalla Z, Argenziano G, et al. The dermatoscopic universe of basal cell carcinoma. Dermatol Pract Concept 2014;4:11-24. https://doi.org/10.5826/dpc.0403a02

53 Betti R, Gualandri L, Cerri A, et al. Clinical features and histologic pattern analysis of pigmented basal cell carcinomas in an Italian population. J Dermatol 1998;25:691-4. https://doi. org/10.1111/j.1346-8138.1998.tb02484.x

54 Jain M, Madan NK, Agarwal S, et al. Pigmented basal cell carcinoma: cytological diagnosis and differential diagnoses. J Cytol 2012;29:2735. http://www.jcytol.org/text.asp?2012/29/4/273/103952

55 Altamura D, Menzies SW, Argenziano G, et al. Dermatoscopy of basal cell carcinoma: morphologic variability of global and local features and accuracy of diagnosis. J Am Acad Dermatol 2010;62:67-75. https://doi.org/10.1016/j.jaad.2009.05.035

56 Russell EB, Carrington PR, Smoller BR. Basal cell carcinoma: a comparison of shave biopsy versus punch biopsy techniques in subtype diagnosis. J Am Acad Dermatol 1999;41:69-71. https://doi.org/10.1016/ s0190-9622(99)70409-3

57 Wolberink EA, Pasch MC, Zeiler M, et al. High discordance between punch biopsy and excision in establishing basal cell carcinoma subtype: analysis of 500 cases. J Eur Acad Dermatol Venereol 2013;27:985-9. https://doi.org/10.1111/j.1468-3083.2012.04628.x
58 Telfer NR, Colver GB, Morton CA; British Association of D. Guidelines for the management of basal cell carcinoma. Br J Dermatol 2008;159:35-48. https://doi.org/10.1111/j.1365-2133.2008.08666.x

59 Bichakjian CK, Olencki T, Aasi SZ, et al. Basal cell skin cancer, version 1.2016, NCCN clinical practice guidelines in oncology. J Natl Compr Canc Netw 2016;14:574-97. https://doi.org/10.6004/ jnccn.2016.0065

60 Leibovitch I, Huilgol SC, Selva D, et al. Basal cell carcinoma treated with Mohs surgery in Australia III. Perineural invasion. J Am Acad Dermatol 2005;53:458-63. https://doi.org/10.1016/j.jaad.2005.04.089

61 Brown CI, Perry AE. Incidence of perineural invasion in histologically aggressive types of basal cell carcinoma. Am J Dermatopathol 2000;22:123-5.

62 Bogelund FS, Philipsen PA, Gniadecki R. Factors affecting the recurrence rate of basal cell carcinoma. Acta Derm Venereol 2007;87:3304. https://doi.org/10.2340/00015555-0236

63 Von Hoff DD, LoRusso PM, Rudin CM, et al. Inhibition of the hedgehog pathway in advanced basal-cell carcinoma. N Engl J Med 2009;361:1164-72. https://doi.org/10.1056/NEJMoa0905360

64 Ganti AK, Kessinger A. Systemic therapy for disseminated basal cell carcinoma: an uncommon manifestation of a common cancer. Cancer Treat Rev 2011;37:440-3. https://doi.org/10.1016/j.ctrv.2010.12.002

65 McCusker M, Basset-Seguin N, Dummer R, et al. Metastatic basal cell carcinoma: prognosis dependent on anatomic site and spread of disease. Eur J Cancer 2014;50:774-83. https://doi.org/10.1016/j. ejca.2013.12.013

66 Walling HW, Fosko SW, Geraminejad PA, et al. Aggressive basal cell carcinoma: presentation, pathogenesis, and management. Cancer Metastasis Rev 2004;23:389-402. https://doi.org/10.1023/ B:CANC.0000031775.04618.30

67 Batra RS, Kelley LC. A risk scale for predicting extensive subclinical spread of nonmelanoma skin cancer. Dermatol Surg 2002;28:107-12; discussion 112. https://doi.org/10.1046/j.1524-4725.2002.02902.x

68 Crowson AN. Basal cell carcinoma: biology, morphology and clinical implications. Mod Pathol 2006;19(Suppl 2):S127-47. https://doi. org/10.1038/modpathol.3800512

69 Goldenberg G, Golitz LE, Fitzpatrick J. Histopathology of skin cancer. In: Stockfleth E, Rosen T, Schumaak S, editors. Managing skin cancer. Berlin Heidleberg: Springer-Verlag; 2010, Chapter 2. https:// doi.org/10.1007/978-3-540-79347-2_2

70 Fan H, Khavari PA. Sonic hedgehog opposes epithelial cell cycle arrest. J Cell Biol 1999;147:71-6. https://doi.org/10.1083/jcb.147.1.71

71 Kraft S, Granter SR. Molecular pathology of skin neoplasms of the head and neck. Arch Pathol Lab Med 2014;138:759-87. https://doi. org/10.5858/arpa.2013-0157-RA

72 Greinert R. Skin cancer: new markers for better prevention. Pathobiology 2009;76:64-81. https://doi.org/10.1159/000201675

73 Witmanowski H, Szychta P, Blochowiak K, et al. Basal cell nevus syndrome (Gorlin-Goltz syndrome): genetic predisposition, clinical picture and treatment. Postepy Dermatol Alergol 2017;34:381-7. https://doi.org/10.5114/ada.2017.69323

74 Pellegrini C, Maturo M, Di Nardo L, et al. Understanding the molecular genetics of basal cell carcinoma. Int J Mol Sci 2017;18:2485. https://doi.org/10.3390/ijms18112485

75 Vinagre J, Pinto V, Celestino R, et al. Telomerase promoter mutations in cancer: an emerging molecular biomarker? Virchows Arch 2014;465:119-33. https://doi.org/10.1007/s00428-014-1608-4

76 Populo H, Boaventura P, Vinagre J, et al. TERT promoter mutations in skin cancer: the effects of sun exposure and X-irradiation. J Invest Dermatol 2014;134:2251-7. https://doi.org/10.1038/jid.2014.163

77 Gaspar TB, Sa A, Lopes JM, et al. Telomere maintenance mechanisms 
in cancer. Genes (Basel) 2018;9:pii:E241. https://doi.org/10.3390/ genes 9050241

78 Correia de Sa TR, Silva R, Lopes JM. Basal cell carcinoma of the skin (part 1): epidemiology, pathology and genetic syndromes. Future Oncol 2015;11:3011-21. https://doi.org/10.2217/fon.15.246

79 Silverman MK, Kopf AW, Bart RS, et al. Recurrence rates of treated basal cell carcinomas. Part 3: surgical excision. J Dermatol Surg Oncol 1992;18:471-6. https://doi.org/10.1111/j.1524-4725.1992.tb03307.x

80 Silverman MK, Kopf AW, Grin CM, et al. Recurrence rates of treated basal cell carcinomas. Part 2: curettage-electrodesiccation. J Dermatol Surg Oncol 1991;17:720-6. https://doi.org/10.1111/j.1524-4725.1991. tb03425.x

81 Nagore E, Grau C, Molinero J, et al. Positive margins in basal cell carcinoma: relationship to clinical features and recurrence risk. A retrospective study of 248 patients. J Eur Acad Dermatol Venereol 2003;17:167-70. https://doi.org/10.1046/j.1468-3083.2003.00535.x

82 Gulleth Y, Goldberg N, Silverman RP, et al. What is the best surgical margin for a Basal cell carcinoma: a meta-analysis of the literature. Plast Reconstr Surg 2010;126:1222-31. https://doi.org/10.1097/ PRS.0b013e3181ea450d

83 Rowe DE, Carroll RJ, Day CL Jr. Mohs surgery is the treatment of choice for recurrent (previously treated) basal cell carcinoma. J Dermatol Surg Oncol 1989;15:424-31. https://doi. org/10.1111/j.1524-4725.1989.tb03249.x

84 Kimyai-Asadi A, Alam M, Goldberg LH, et al. Efficacy of narrowmargin excision of well-demarcated primary facial basal cell carcinomas. J Am Acad Dermatol 2005;53:464-8. https://doi.org/10.1016/j. jaad.2005.03.038

85 Luz FB, Ferron C, Cardoso GP. Analysis of effectiveness of a surgical treatment algorithm for basal cell carcinoma. An Bras Dermatol 2016;91:726-31. https://doi.org/10.1590/abd1806-4841.20165919

86 Luz FB, Ferron C, Cardoso GP. Surgical treatment of basal cell carcinoma: an algorithm based on the. An Bras Dermatol 2015;90:377-83. https://doi.org/10.1590/abd1806-4841.20153304

87 Lane JE, Kent DE. Surgical margins in the treatment of nonmelanoma skin cancer and mohs micrographic surgery. Curr Surg 2005;62:51826. https://doi.org/10.1016/j.cursur.2005.01.003
88 Leibovitch I, Huilgol SC, Selva D, et al. Basal cell carcinoma treated with Mohs surgery in Australia II. Outcome at 5-year followup. J Am Acad Dermatol 2005;53:452-7. https://doi.org/10.1016/j. jaad.2005.04.087

89 Finley EM. The principles of mohs micrographic surgery for cutaneous neoplasia. Ochsner J 2003;5:22-33

90 Batra RS, Kelley LC. Predictors of extensive subclinical spread in nonmelanoma skin cancer treated with Mohs micrographic surgery. Arch Dermatol 2002;138:1043-51. https://doi.org/10.1001/archderm.138.8.1043

91 Zhang N, Yin Y, Xu SJ, et al. 5-Fluorouracil: mechanisms of resistance and reversal strategies. Molecules 2008;13:1551-69. https://doi. org/10.3390/molecules13081551

92 Arits AH, Mosterd K, Essers BA, et al. Photodynamic therapy versus topical imiquimod versus topical fluorouracil for treatment of superficial basal-cell carcinoma: a single blind, non-inferiority, randomised controlled trial. Lancet Oncol 2013;14:647-54. https://doi. org/10.1016/S1470-2045(13)70143-8

93 Love WE, Bernhard JD, Bordeaux JS. Topical imiquimod or fluorouracil therapy for basal and squamous cell carcinoma: a systematic review. Arch Dermatol 2009;145:1431-8. https://doi.org/10.1001/ archdermatol.2009.291

94 Silverman MK, Kopf AW, Gladstein AH, et al. Recurrence rates of treated basal cell carcinomas. Part 4: X-ray therapy. J Dermatol Surg Oncol 1992;18:549-54. https://doi.org/10.1111/j.1524-4725.1992. tb03508.x

95 Fellner C. Vismodegib (erivedge) for advanced basal cell carcinoma. P T 2012;37:670-82. www.ncbi.nlm.nih.gov/pmc/articles/ PMC3541861/

96 Sekulic A, Migden MR, Oro AE, et al. Efficacy and safety of vismodegib in advanced basal-cell carcinoma. N Engl J Med 2012;366:21719. https://doi.org/10.1056/NEJMoa1113713

97 American College of Mohs Surgery. About Mohs Surgery. 2017. www.mohscollege.org/about/about-mohs-surgery (accessed December 2017).

98 The Skin Cancer Foundation. Mohs surgery step by step. New York; 2017. https://www.skincancer.org/skin-cancer-information/mohssurgery/step-by-step 